University of Nebraska - Lincoln

DigitalCommons@University of Nebraska - Lincoln

U.S. Department of Veterans Affairs Staff

Publications

U.S. Department of Veterans Affairs

2006

\title{
Sulfation of tibolone metabolites by human postmenopausal liver and small intestinal sulfotransferases (SULTs)
}

\author{
Min Wang \\ Creighton University Medical Center \\ Christopher C. Ebmeier \\ Creighton University Medical Center \\ John R. Olin \\ Creighton University Medical Center
}

Robert J. Anderson

Creighton University Medical Center, Robert.Anderson4@med.va.gov

Follow this and additional works at: https://digitalcommons.unl.edu/veterans

Wang, Min; Ebmeier, Christopher C.; Olin, John R.; and Anderson, Robert J., "Sulfation of tibolone metabolites by human postmenopausal liver and small intestinal sulfotransferases (SULTS)" (2006). U.S. Department of Veterans Affairs Staff Publications. 84.

https://digitalcommons.unl.edu/veterans/84

This Article is brought to you for free and open access by the U.S. Department of Veterans Affairs at DigitalCommons@University of Nebraska - Lincoln. It has been accepted for inclusion in U.S. Department of Veterans Affairs Staff Publications by an authorized administrator of DigitalCommons@University of Nebraska - Lincoln. 


\title{
Sulfation of tibolone metabolites by human postmenopausal liver and small intestinal sulfotransferases (SULTs)
}

\author{
Min Wang ${ }^{1}$, Christopher C. Ebmeier, John R. Olin, Robert J. Anderson* \\ Section of Endocrinology, Veterans Affairs Medical Center, Creighton University Medical Center, Omaha, NE, USA
}

\section{A R T I C L E I N F O}

\section{Article history:}

Received 12 October 2005

Received in revised form 3

November 2005

Accepted 9 November 2005

Published on line 19 December 2005

\section{Keywords:}

SULT

Tibolone metabolites

Sulfation

Liver

Small intestine

\begin{abstract}
A B S T R A C T
Sulfation is a major pathway in humans for the biotransformation of steroid hormones and structurally related therapeutic agents. Tibolone is a synthetic steroid used for the treatment for climacteric symptoms and postmenopausal osteoporosis. Sulfation inactivates the hydroxylated metabolites, $3 \alpha$-hydroxytibolone ( $3 \alpha-\mathrm{OH}$-tibolone) and $3 \beta$-hydroxytibolone ( $3 \beta-\mathrm{OH}$-tibolone), and contributes to the regulation of tissue responses to tibolone. We detected SULT1A1, SULT1A3, SULT1E1 and SULT2A1 mRNA expression by RT-PCR in postmenopausal liver and small intestine. Liver pool $(n=5)$ SULT activities measured with tibolone substrates reflected COS-1 expressed SULT2A1 and SULT1E1 activities. Liver SULT2A1 activity ( $1.8 \pm 0.3$ units/mg protein, $n=8$, mean $\pm \mathrm{SEM})$, and activities with $3 \alpha-\mathrm{OH}$ tibolone $(0.6 \pm 0.1, n=8)$ and $3 \beta-O H$-tibolone $(0.9 \pm 0.2, n=8)$ were higher than SULT1E1 activities $(<0.05, n=10)$. SULT1E1 activities were low or not detected in many samples. Mean small intestinal activities were $0.03 \pm 0.01$ with $3 \alpha$-OH-tibolone and $0.04 \pm 0.01$ with $3 \beta-\mathrm{OH}$ tibolone $(n=3)$. In conclusion, SULT2A1 is the major endogenous enzyme responsible for sulfation of the tibolone metabolites in human postmenopausal tissues. The results support the occurrence of pre-receptor enzymatic regulation of hydroxytibolone metabolites and prompt further investigation of the tissue-selective regulation of tibolone effects.
\end{abstract}

(c) 2005 Elsevier Inc. All rights reserved.

\section{Introduction}

Tibolone (Livial) is a synthetic steroid that has been used extensively for the prevention of postmenopausal osteoporosis [1,2] and for the treatment of climacteric symptoms [3]. It is the prototype of a compound that acts as a selective tissue estrogen activity regulator (STEAR) [4]. A key element in this tissue specific regulation of estrogen activity is mediated through enzymatic mechanisms that activate or inactivate estrogenic compounds prior to their interaction with a steroid receptor [5]. After oral administration, tibolone is metabolized into three biologically active metabolites. The $3 \alpha$-hydroxytibolone ( $3 \alpha$-OH-tibolone) and $3 \beta$-hydroxytibolone (3 $\beta$-OH-tibolone) metabolites have estrogen agonist properties, and the $\Delta^{4}$-ketoisomer has progestogenic and androgenic effects. Sulfation of the hydroxytibolone metabolites by sulfotransferase enzymes (SULTs) renders these metabolites receptor-inactive and reduces their estrogenic effects. SULT activity may account for the clinical effects of tibolone treatment that include an unchanged mammographic breast density in most women, less symptoms related to the breast, and less vaginal bleeding when compared with usual hor-

\footnotetext{
This work was supported by a grant from N.V. Organon Inc. and the VA Medical Research Service.

* Corresponding author at: Veterans Affairs Medical Center, 4101 Woolworth Ave, Omaha, NE 68105, USA. Tel.: +1 402 346 8800x4312; fax: +1 4029775624 .

E-mail address: Robert.Anderson4@med.va.gov (R.J. Anderson).

${ }^{1}$ Present address: Department of Obstetrics and Gynecology, The Second Affiliated Hospital, China Medical University, Shenyang, PR China. 
mone replacement therapy [6-10]. An additional protective effect of tibolone in these tissues is the inhibition of sulfatase activity by the tibolone metabolites in breast and endometrial cells $[5,11]$. By contrast, the lack of steroid SULT activity and minimal inhibition of sulfatase activity by tibolone in bone cells allow free hydroxytibolone metabolites to activate the estrogen receptor $(\alpha)$ in bone and to decrease bone resorption $[5,11]$. Thus, tibolone, as a STEAR, does not behave as a selective estrogen receptor modulator (SERM), but rather acts by enzymatic pre-receptor regulation of the estrogenic active metabolites.

Sulfated hydroxytibolone metabolites have been found in the circulation, supporting the involvement of SULTs in the regulation and metabolism of tibolone. In the cytosolic SULT superfamily there are at least 10 human SULT genes [12]. Fusion proteins of two steroid SULTs expressed in bacteria have been shown to use tibolone metabolites as substrates [13]. However, the exact SULT isozymes involved in the sulfation of the active tibolone metabolites in postmenopausal human liver and other tissues have yet to be fully characterized.

In this study we tested samples of human premenopausal and postmenopausal liver and small intestine for SULT activities with tibolone metabolites. We then used postmenopausal liver to establish biochemical properties and radiochemical assays with the substrates $3 \alpha-\mathrm{OH}$-tibolone and $3 \beta-\mathrm{OH}-$ tibolone. These tools allowed us to document the postmenopausal liver contribution to the sulfation of hydroxytibolone metabolites. Because the cytosolic liver preparation represented a composite of SULT activities, we also compared the kinetic parameters of cDNA expressed SULT activities to the liver SULT activities when tested with the tibolone metabolites.

\section{Experimental}

\subsection{Materials}

$\left[{ }^{35} \mathrm{~S}\right]$ Phosphoadenosine-5-phosphosulfate ([ $\left.{ }^{35} \mathrm{~S}\right]$-PAPS, specific activity from 2.4 to $3.0 \mathrm{Ci} / \mathrm{mmol}$ ) was purchased from Perkin-Elmer LAS, Shelton, CT. 2-Difluoro-methyloestrone-3O-sulphamate (EMATE), the hydroxytibolone metabolites and their respective sulfated compounds were provided by Dr. H.J. Kloosterboer (Organon, Oss, The Netherlands). Dithiothreitol (DTT) was purchased from CalBiochem, La Jolla, CA. Bovine serum albumin (BSA), sodium chloride $(\mathrm{NaCl})$, 2,6-dichloro4-nitrophenol (DCNP) and magnesium chloride $\left(\mathrm{MgCl}_{2}\right)$ were obtained from Sigma Chemical Company, St. Louis, MO. Protein assay reagent was obtained from Bio-Rad Laboratories, Richmond, CA and Bio-Safe II scintillation fluor was purchased from Research Products International Corp., Mount Prospect, IL. COS-1 cells were obtained from the American Type Culture Collection (ATCC), Rockville, MD. The human liver SULT1A1, SULT1A2, SULT1A3, SULT1E1, SULT1C2, SULT2A1, SULT2B1_v1 and SULT2B1_v2 cDNAs were gifts from Dr. Weinshilboum [14-18]. Trizol reagents, Superscript First-Strand Synthesis kit, Lipofectamine, Platinum PCR Supermix kit were purchased from Invitrogen Corp., Carlsbad, CA.

\subsection{Tissue samples and cytosol preparations}

Both the IRB and the Research and Development Committee of the VA-Nebraska Western Iowa Health Care System approved these studies. Frozen human liver premenopausal $(37.8 \pm 6.3$ years, mean \pm S.D., $n=5)$ and postmenopausal $(69.1 \pm 7.4$ years, mean \pm S.D., $n=10)$ samples, and small intestine premenopausal $(39.2 \pm 5.4$ years, mean \pm S.D., $n=5)$ and postmenopausal ( $71 \pm 10$ years, mean \pm S.D., $n=11$ ) samples were obtained from the National Disease Research Interchange (NDRI). All samples were obtained from Caucasian subjects at autopsy except for one premenopausal liver surgical sample and two premenopausal small intestine surgical samples. Tissue was stored at $-80^{\circ} \mathrm{C}$ until preparation.

Tissue samples were homogenized for $15-30 \mathrm{~s}$ in four volumes of $2.5 \mathrm{mM}$ DTT, $1.25 \mathrm{mM}$ disodium EDTA in $5 \mathrm{mM}$ potassium phosphate buffer, pH 7.5, with a Polytron Tissue Homogenizer (Kinematica, Lucerne, Switzerland). Homogenates were centrifuged at $12,900 \times \mathrm{g}$ for $10 \mathrm{~min}$ at $4^{\circ} \mathrm{C}$. The supernatant was removed and centrifuged at $100,000 \times g$ for $1 \mathrm{~h}$ at $4{ }^{\circ} \mathrm{C}$. Aliquots of the high speed supernatant (HSS) were stored at $-80^{\circ} \mathrm{C}$ until assay. Equal volumes of each HSS were pooled for each tissue. COS-1 cells were transfected with SULT cDNA and processed by our previously published procedures [19-22].

\subsection{RNA extraction and RT-PCR}

Total RNA was extracted from tissue using Trizol reagent according to manufacturer's instructions (Invitrogen). First strand cDNA synthesis was performed using Superscript II RT with oligo dT priming for $1 \mu \mathrm{g}$ total RNA by manufacturer's instructions. Each liver cDNA (87 ng), SULT1A1, SULT1E1 and SULT2A1 plasmid cDNAs (1 ng) were used as the templates for PCR with $0.1 \mathrm{nmol}$ each SULT specific primers [21,23,24]. PCR was performed using Platinum PCR Supermix (Invitrogen) and an Eppendorf thermal cycler. Transcripts were amplified by an initial denaturation at $94^{\circ} \mathrm{C}$ for $2 \mathrm{~min}$, followed by 35 cycles of $94^{\circ} \mathrm{C}$ for $30 \mathrm{~s}, 55^{\circ} \mathrm{C}$ (SULTs $1 \mathrm{E} 1$ and $2 \mathrm{~A} 1$ ) or $65^{\circ} \mathrm{C}$ (SULT1A1) for $1 \mathrm{~min} 15 \mathrm{~s}$ and $72^{\circ} \mathrm{C}$ for $2 \mathrm{~min}$. The PCR products were resolved by $2 \%$ agarose gel electrophoresis and detected with ethidium bromide.

\subsection{Sulfotransferase (SULT) and protein assays}

SULT activities were measured by the method of Foldes and Meek [25], as modified by Anderson and Liebentritt [26]. Optimal conditions with hydroxytibolone as the substrate were established with regard to $\mathrm{pH}$, protein and substrate concentrations. Assays with the hydroxytibolone substrates were performed with 2.5 and $3.5 \mu$ g protein per assay tube for the liver pool HSS and the small intestinal HSS, respectively. SULT1E1 and SULT2A1 were assayed with 1.1 and $0.7 \mu \mathrm{g}$ protein per assay tube, respectively. The final concentrations used in the assays were $1 \mu \mathrm{M} 3 \alpha$-OH-tibolone and $4 \mu \mathrm{M} 3 \beta-\mathrm{OH}$-tibolone with liver and small intestinal HSS and $1 \mu \mathrm{M}$ hydroxytibolone substrates for the activity screen of expressed SULT enzymes. The $\mathrm{pH}$ values for potassium phosphate buffers at a final concentration of $8.3 \mathrm{mM}$ were 7.5 for the liver and small intestine, 6.5 for expressed SULT1E1 with hydroxytibolone, and 6.0 for expressed SULT2A1 with 
$3 \alpha-\mathrm{OH}$-tibolone and 7.0 with $3 \beta-\mathrm{OH}$-tibolone. $\mathrm{A} \mathrm{MgCl}_{2}$ concentration of $1.0 \mathrm{mM}$ was used with hydroxytibolone metabolite assays and $0.3 \mathrm{mM}$ in assays with estrone (SULT1E1) and DHEA (SULT2A1) as substrates. Assays of tissue SULT1A1, 1A3, 1E1 and $2 \mathrm{~A} 1$ activities were performed with their respective model substrates as previously published $[19,27]$. Reactions were incubated at $37^{\circ} \mathrm{C}$ for $30 \mathrm{~min}$ and blank samples containing no sulfuryl group acceptor substrate were used as controls. Radioactivity was measured using a Packard model 1600 TR liquid scintillation counter. One unit of enzyme activity represented the formation of $1 \mathrm{nmol}$ of sulfated product per hour of incubation at $37^{\circ} \mathrm{C}$. Assays were performed in triplicate and values reported are the means of three determinations unless otherwise specified. Protein concentrations were measured by the dye binding method of Bradford [28] with BSA as the standard.

\subsection{Thermal stability}

Thermal stability of enzyme activities was tested by the methods of Reiter et al. [29] as modified by Anderson et al. [26,30]. Aliquots of diluted HSS were pre-incubated for $15 \mathrm{~min}$ at various temperatures prior to assay. Aliquots of the same diluted preparation were kept on ice as a control. Each aliquot was then assayed for SULT activity.

\subsection{HPLC}

HPLC analyses were performed at room temperature using a Waters RP18 $3.5 \mu \mathrm{M}, 3.0 \mathrm{~mm} \times 15 \mathrm{~mm}$ SymmetryShield column, a Beckman 126 solvent module, a 166 variable wavelength detector and a Rainin 7725 manual injector. Solvents were $0.1 \%(\mathrm{v} / \mathrm{v})$ trifluoroacetic acid (TFA) in water (Solvent $\mathrm{A}$ ) and $0.1 \%(\mathrm{v} / \mathrm{v})$ TFA in acetonitrile (ACN) (Solvent B). Tibolone metabolites were separated with the following solvent proportioning method: 0-5 min, 20\% B; 5-30 min, 20-70\% B; $30-33 \mathrm{~min}, 70-20 \% \mathrm{~B}$; and re-equilibration at $20 \% \mathrm{~B}$. Flow rate was $0.5 \mathrm{~mL} / \mathrm{min}$. Standard peaks were detected at $210 \mathrm{~nm}$ and injections were $20 \mu \mathrm{L}$ with a Hamilton $25 \mu \mathrm{L}$ syringe. To confirm sulfation reaction products, each reaction mixture was injected onto the column and fractions were collected at $1 \mathrm{~min}$ intervals.

\subsection{Data analysis}

Apparent $K_{m}$ and $V_{\max }$ values were calculated by the direct linear plot method of Eisenthal and Cornish-Bowden [31] using the Enzpak 3 program by Williams (Elsevier-Biosoft, Cambridge, UK). The 50\% inactivation temperature $\left(T_{50}\right), 50 \%$ inhibition concentration $\left(\mathrm{IC}_{50}\right)$ with DCNP and percentage of increased activity with $\mathrm{NaCl}$ were determined using a curvefitting program. Linear regression analysis was done by the Spearman rank correlation method for non-parametric statistics (Prism3, GraphPad Software, San Diego, California).

\section{Results}

\subsection{RT-PCR detection of human SULT expression}

Reverse transcription-polymerase chain reaction (RT-PCR) experiments were performed with total RNA extracted from individual premenopausal and postmenopausal human livers and SULT gene-specific primers for SULT1A1, 1A3, 1E1, 2A1, 2B1_v1 and 2B1_v2. Liver and small intestinal samples were tested to confirm whether mRNA predicted the presence of activity for SULT1E1 and SULT2A1. SULT1A1, SULT1E1 and SULT2A1 mRNAs were expressed in all 10 postmenopausal liver samples (Fig. 1). In separate studies of mRNA expression, SULT1A3 was present in all liver samples and SULT2B1_v2 mRNA was expressed in seven samples, while SULT2B1_v1 mRNA was not detected in any of the liver samples (data not shown). Six individual postmenopausal small intestinal samples were tested as a representative sampling. All were positive for SULT1A1, five of six were positive for SULT1A3 and only two samples were both positive for SULT1E1, SULT2A1 and SULT 2B1_v2 (data not shown).

\subsection{Postmenopausal human liver SULT activities with tibolone metabolites}

A pool of the postmenopausal liver HSS was used to characterize SULT activities with hydroxytibolone substrates. Human liver SULT activities with hydroxytibolone increased in a linear fashion with HSS protein up to at least $25 \mu \mathrm{g}$ protein per

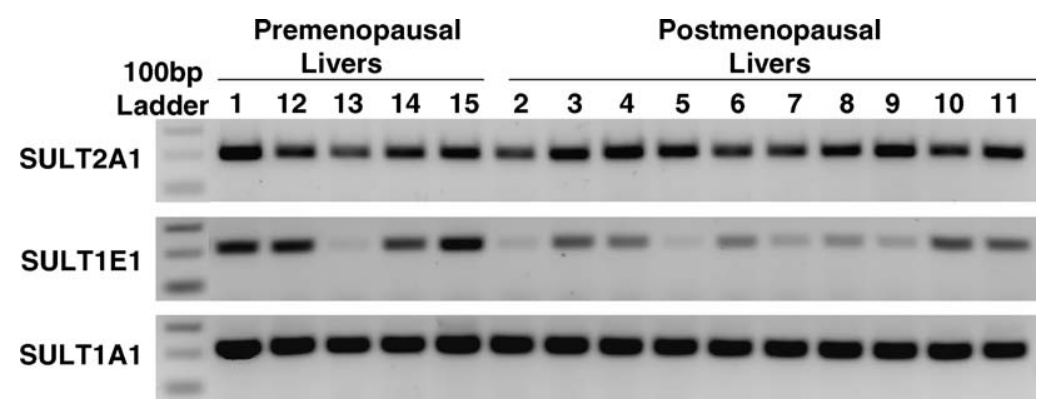

Fig. 1 - RT-PCR of SULT2A1, SULT1E1 and SULT1A1 expression in individual premenopausal and postmenopausal liver tissues. SULT1A1 expression was used as an internal standard. One microgram extracted total RNA from each liver tissue was converted to cDNA and used as the template for PCR with SULT-specific primers as described in Section 2. The first lane on the left is the 100 base pair ladder with 300, 200 and $100 \mathrm{bp}$ bands from the top to the bottom of each gel image. PCR products were separated by $2 \%$ agarose gel electrophoresis and visualized with $0.01 \%$ ethidium bromide and ultraviolet light. 
Table 1 - Biochemical properties of human

postmenopausal liver sulfotransferases

$3 \alpha-\mathrm{OH}$-Tibolone $3 \beta-\mathrm{OH}$-Tibolone

Expressed SULT1E1

$\mathrm{V}_{\max }$ (units/mg protein)

$0.18 \pm 0.05$

$1.22 \pm 0.04$

$0.48 \pm 0.14$

Expressed SULT2A1

$K_{\mathrm{m}}(\mu \mathrm{M})$

$0.79 \pm 0.12$

$4.9 \pm 0.2$

$\mathrm{V}_{\max }$ (units/mg protein)

$2.1 \pm 0.2$

$0.56 \pm 0.09$

$5.9 \pm 0.4$

Postmenopausal liver SULTs

$\mathrm{K}_{\mathrm{m}}(\mu \mathrm{M})$

$0.18 \pm 0.04$

$0.42 \pm 0.07$

$\mathrm{V}_{\max }$ (units/mg protein)

$0.9 \pm 0.1$

$1.3 \pm 0.2$

PAPS $K_{\mathrm{m}}(\mu \mathrm{M}) \quad 0.060 \pm 0.002$

PAPS $V_{\max }$ (units/mg protein) $1.40 \pm 0.02$

$0.060 \pm 0.004$

$1.81 \pm 0.03$

$\mathrm{T}_{50}\left({ }^{\circ} \mathrm{C}\right)$

$43.2 \pm 0.5$

DCNP IC $50(\mu \mathrm{M})$

$190 \pm 50$

$43.1 \pm 0.3$

Activation by $\mathrm{NaCl}(\%)$

$46.1 \pm 4.8$

$180 \pm 15$

$54.6 \pm 7.5$

Results are expressed as the mean \pm SEM of three experiments, each performed with triplicate determinations except for the $T_{50}$ and DCNP studies each performed with six determinations from two experiments.

assay. The chosen final HSS protein of $2.5 \mu \mathrm{g}$ was within the linear range of activity. Optimal SULT activities were found with potassium phosphate, $\mathrm{pH}$ 7.5. Magnesium increases the activities of several SULT enzymes [15,19]. Therefore, $\mathrm{MgCl}_{2}$ concentrations of $1.0-16 \mathrm{mM}$ were tested in the assay. A final $\mathrm{MgCl}_{2}$ concentration of $1.0 \mathrm{mM}$ increased SULT activities by $9.2 \%$ with $3 \alpha-\mathrm{OH}$-tibolone and by $6.2 \%$ with $3 \beta-\mathrm{OH}$-tibolone. Subsequent liver and small intestine SULT assays with hydroxytibolone were performed at $\mathrm{pH} 7.5$ with $1.0 \mathrm{mM} \mathrm{MgCl}_{2}$.

\subsection{Effects of varying hydroxytibolone and PAPS} concentrations

The effect of a range of hydroxytibolone concentrations on SULT activities was determined (Fig. 2). When hydroxytibolone concentrations were evaluated from $16 \mathrm{pM}$ to $128 \mu \mathrm{M}$, substrate inhibition occurred at concentrations above $2 \mu \mathrm{M}$ $3 \alpha$-OH-tibolone and $4 \mu \mathrm{M} 3 \beta-\mathrm{OH}$-tibolone. Apparent $K_{\mathrm{m}}$ values for postmenopausal human liver SULTs with hydroxytibolone were calculated from the means of three experiments with each substrate (Table 1). The optimal concentrations of hydroxytibolone used in subsequent assays of liver and small intestine SULTs were $1 \mu \mathrm{M} 3 \alpha-\mathrm{OH}$-tibolone and $4 \mu \mathrm{M} 3 \beta-\mathrm{OH}$ tibolone.

The effect of varying $\left[{ }^{35} \mathrm{~S}\right]$-PAPS concentrations on SULT activities was determined with constant concentrations of $1 \mu \mathrm{M} 3 \alpha-\mathrm{OH}$-tibolone and $4 \mu \mathrm{M} 3 \beta-\mathrm{OH}$-tibolone. A $\left[{ }^{35} \mathrm{~S}\right]$-PAPS concentration of $0.4 \mu \mathrm{M}$ was used in all assays.

\subsection{Effects of temperature, DCNP inhibition and sodium chloride}

Assays were conducted to compare the thermal stability, DCNP inhibition and the effect of $\mathrm{NaCl}$ on postmenopausal human liver SULT activities with hydroxytibolone substrates. Thermal stability is a sensitive indicator of differences in protein struc-
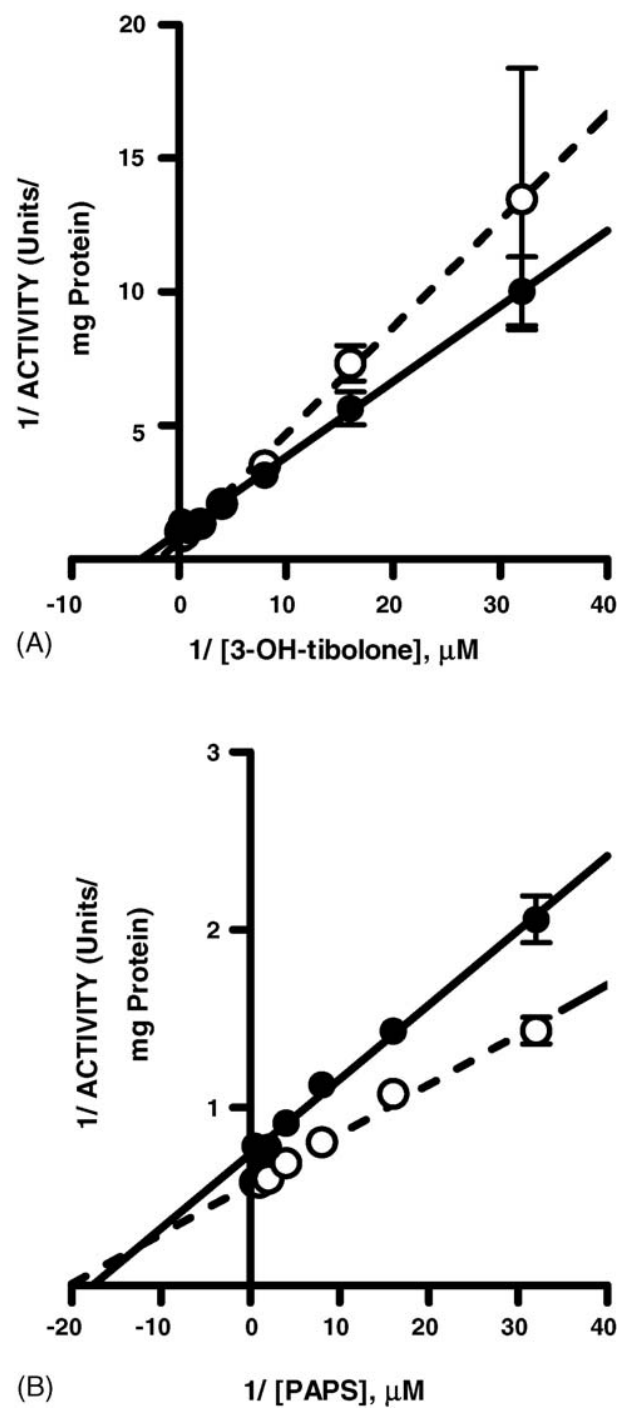

Fig. 2 - Double reciprocal plots with hydroxytibolone substrates. Panel A: Effects of varying $3 \alpha$-hydroxytibolone $(0)$ and $3 \beta$-hydroxytibolone $(O)$ substrate concentrations on sulfation by postmenopausal human liver SULT activities. Each data point represents the mean \pm SEM of three experiments, each performed with triplicate determinations. Panel B: Effects of varying the 3'-phosphoadenosine-5' -phosphosulfate (PAPS) co-substrate concentrations on the sulfation of $1 \mu \mathrm{M}$ $3 \alpha$-OH-tibolone $(0)$ and $4 \mu \mathrm{M} 3 \beta-O H$-tibolone $(O)$ by postmenopausal human liver SULT activities. Each data point represents the mean \pm SEM of six determinations from two experiments.

ture [29]. The patterns of tissue SULT thermal stability when assayed with tibolone might indicate which isozyme was involved. The thermal stability of human liver SULT activities was determined with hydroxytibolone after pre-incubation of tissue aliquots for $15 \mathrm{~min}$ at temperatures from 35 to $47^{\circ} \mathrm{C}$ (Table 1).

Another approach to the characterization of SULT isozymes is the response to the inhibitor DCNP. Human postmenopausal liver SULT activities assayed with hydroxytibolone were mea- 


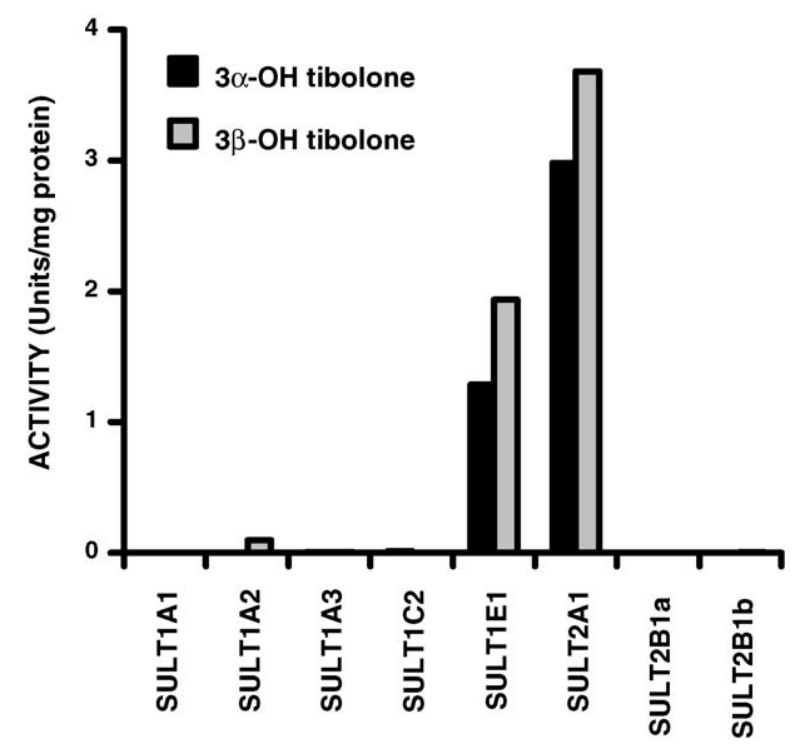

Fig. 3 - Expressed SULT activities with $1 \mu \mathrm{M}$ $3 \alpha$-hydroxytibolone and $3 \beta$-hydroxytibolone metabolites as substrates. The presence of SULT activities in the expressed preparations was tested with appropriate substrates for the enzymes. SULTs 2B1a and 2B1b represent 2B1-V1 and 2B1-V2, respectively.

sured with various concentrations of DCNP (Table 1). IC 50 values for SULT activities with DCNP were similar. $\mathrm{NaCl}$ enhances SULT1E1 and SULT2A1 activities when assayed with the model substrates estrone and DHEA $[15,19]$. In our study, activation was present when the postmenopausal human liver pool was assayed with hydroxytibolone as the substrates in the presence of $\mathrm{NaCl}$ (Table 1). The activation was consistent with the behavior of steroid SULTs 1E1 and 2A1, as opposed to inhibition by $\mathrm{NaCl}$ that occurs with SULT1A1 and SULT1A3 [27].

\subsection{Expressed SULT activity with tibolone metabolites}

Expressed SULT1E1 and SULT2A1 demonstrated excellent activities when screened with assays using $1 \mu \mathrm{M}$ hydroxytibolone as the substrates. Expressed SULT1A1, SULT1A2, SULT1A3, SULT1C2, SULT2B1_V1 and SULT2B1_v2 assayed with the same substrates showed no detectable activities (Fig. 3). Further investigation of expressed SULT1E1 and SULT2A1 was done to determine optimal assay conditions and apparent $K_{\mathrm{m}}$ values with the tibolone metabolites (Table 1 ). These values were equivalent to the apparent $K_{\mathrm{m}}$ values obtained with the postmenopausal liver preparations.

\subsection{Product identification by HPLC}

Radiolabeled hydroxytibolone products were prepared with the optimized assay, separated with reversed phase HPLC and compared to standards. The radiolabeled products of sulfation by postmenopausal liver SULTs, expressed SULT1E1 and SULT2A1 co-eluted with the $3 \beta$-sulfate-hydroxytibolone standards exclusively when $3 \beta-\mathrm{OH}$-tibolone was the substrate. A major product peak that was produced when $3 \alpha$-OH-tibolone was assayed with each SULT preparation co-eluted with the
$3 \alpha$-sulfate-hydroxytibolone standard. In assays with only the liver and expressed SULT2A1 there was a second smaller peak that was not identified because it did not co-elute with any of the available standards.

\subsection{Individual liver activities with tibolone metabolites}

To assess the tissue specific activity of liver SULTs and their contributions to sulfation of tibolone metabolites, individual premenopausal and postmenopausal liver samples were assayed with $25 \mathrm{nM}$ estrone (SULT1E1), $5 \mu \mathrm{M}$ DHEA (SULT2A1), $1 \mu \mathrm{M} 3 \alpha-\mathrm{OH}$-tibolone and $4 \mu \mathrm{M} 3 \beta-\mathrm{OH}$-tibolone as the substrates. (Figs. 4 and 5). Activities with the premenopausal livers were 0.6 with estrone $(n=2), 3.1 \pm 0.8$ with DHEA $(n=5), 2.9 \pm 0.9$ with $3 \alpha-\mathrm{OH}$-tibolone and $4.0 \pm 1.3$ with $3 \beta-\mathrm{OH}$-tibolone (both $n=5$, units/mg protein, mean \pm SEM, Fig. 4). Each activity measured with DHEA or hydroxytibolone as the substrates was higher than the activity with estrone. SULT activities of the postmenopausal livers were $<0.05(n=10)$ with estrone (SULT1E1), $1.8 \pm 0.3(n=8)$ with DHEA (SULT2A1), $0.6 \pm 0.1$ and $0.9 \pm 0.2$ with $3 \alpha-\mathrm{OH}$-tibolone and $3 \beta-\mathrm{OH}$-tibolone, respectively $(n=8)$ (units/mg protein, mean \pm SEM, Fig. 5). Samples with undetectable SULT1E1 activity were tested with EMATE, a sulfatase inhibitor. Sulfatase activity would degrade the radiolabeled product and obscure the presence of SULT activity. There were no increases in measured SULT1E1 activity in the presence of EMATE. In addition, there was no relationship between the SULT1E1 tissue activities and time from death to autopsy to explain loss of activity, but the sample number was small (data not shown). The internal liver standard used to monitor SULT1E1 assays was a pool of samples from three male donors. The SULT1E1 activity was several-fold higher than postmenopausal samples and the liver HSS pool stored at $-80^{\circ} \mathrm{C}$ retained activity throughout the 2 years of this study.

\subsection{Small intestine activities with tibolone metabolites}

Human gastrointestinal tissue contains multiple SULT enzymes that include SULTs 1A1, 1A3, 1E1 and 2A1 [32]. These enzymes are differentially distributed throughout the gut [33] and they contribute to the metabolism of hydroxytibolone metabolites within the intestine. We tested both premenopausal and postmenopausal small intestinal HSS samples for SULT activities in pooled preparations with the same substrate concentrations used with the liver samples. SULT1A1 activities of 2.7 and 0.2 units/mg protein were present in premenopausal and postmenopausal samples, respectively, and SULT1A3 activities were 12.8 and 0.2 units/mg protein with premenopausal and postmenopausal samples, respectively. Activities with the premenopausal small intestinal pool $(n=4)$ were $<0.1$ units/mg protein with estrone (SULT1E1) and 0.2 units/mg protein with DHEA (SULT2A1). Activities with the postmenopausal small intestinal pool $(n=6)$ were not detectable with estrone or DHEA. Mean activities of three individual samples with measurable levels were $0.03 \pm 0.01$ with $3 \alpha-\mathrm{OH}$-tibolone and $0.04 \pm 0.01$ with $3 \beta-\mathrm{OH}$-tibolone (units/mg protein, mean $\pm \mathrm{SEM}$ ). It was not possible to determine the exact location of the intestinal tissue samples to 

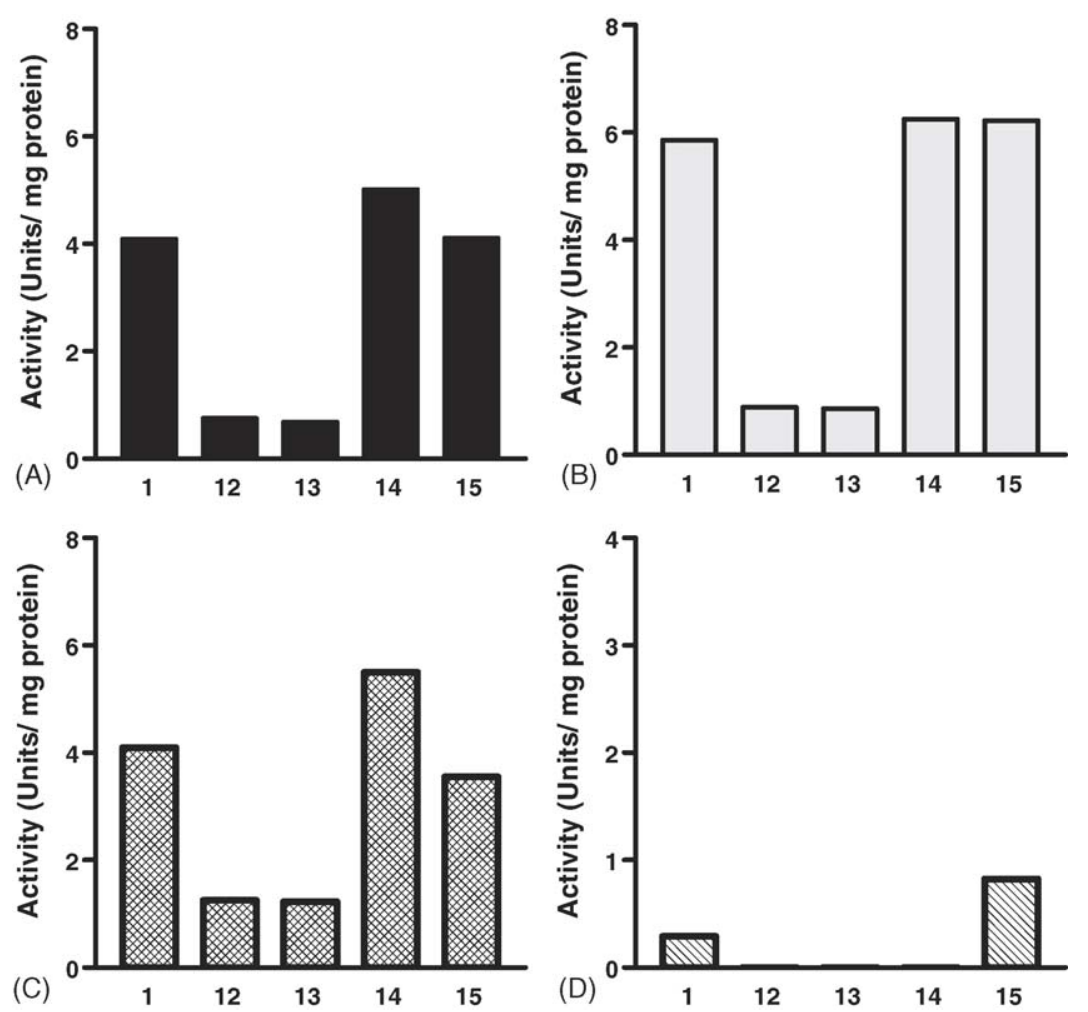

Fig. 4 - Individual premenopausal liver SULT activities assayed with $1 \mu \mathrm{M} 3 \alpha$-hydroxytibolone (Panel A), $4 \mu \mathrm{M}$

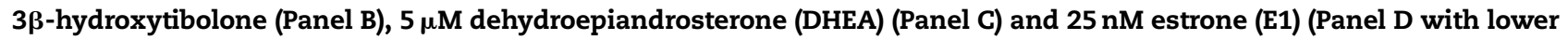
activity scale). Activities with hydroxytibolone substrates represent a composite of liver SULT activities (Panels A and B). Results with substrates estrone and DHEA indicate SULT1E1 and SULT2A1 activities, respectively. Each bar represents the mean of three determinations.

discern whether the sampling itself contributed to the differences observed. The mean SULT2A1 activity of the two premenopausal surgical small intestine samples was similar to the higher SULT2A1 activity of one of the three premenopausal autopsy samples. Other premenopausal surgical small intestinal SULT activities showed no distinct patterns that distinguished them from autopsy small intestinal sample activities. In these small groups, there were no trends of negative correlations between SULT activities and length of time from death to autopsy in liver or small intestine $(r=0.0, n=8$ for postmenopausal livers; no meaningful trend was evident for the three small intestinal samples with activity).

\section{Discussion}

Tibolone represents the initial steroid in the class of agents identified as selective tissue estrogen activity regulators (STEAR) [4]. This study is the first systematic investigation of human postmenopausal tissue sulfation of tibolone metabolites as one of the tissue-specific components in the prereceptor enzymatic regulation of the estrogenic effects of tibolone. We have identified human premenopausal and postmenopausal liver and small intestine SULT activities involved in the sulfation of the hydroxytibolone metabolites. Assays established for these activities represented a combination of SULT activities because of the documented presence of multiple SULTs in these tissues [32-34]. Biochemical properties found for postmenopausal liver SULTs with the tibolone metabolites as substrates were similar to those described with cDNA-expressed human SULT1E1 and SULT2A1 activities (Table 1). For example, the apparent $K_{m}$ values for the postmenopausal liver SULTs and expressed SULT1E1 with $3 \alpha$ OH-tibolone as the substrate were $0.18 \mu \mathrm{M}$ for each preparation. Apparent $K_{\mathrm{m}}$ values for all three preparations assayed with $3 \beta-\mathrm{OH}$-tibolone were essentially the same, from 0.42 to $0.56 \mu \mathrm{M}$. The individual liver activity data and HPLC analyses of assay products with normal and postmenopausal livers and expressed SULT preparations indicated that SULT2A1 was the major contributor to the sulfation of $3 \alpha-\mathrm{OH}$-tibolone and $3 \beta$ OH-tibolone.

Liver SULT2A1 activities measured with DHEA as the substrate varied 3.7-fold in the premenopausal samples and 23-fold in the postmenopausal samples. Previous studies of human female surgical samples have documented a four-fold variation in liver SULT2A1 activity [34] and a 15-fold variation in small intestine SULT2A1 immunoreactive protein [32]. Genetic polymorphisms of SULT2A1 associated with decreased activity have been described only in African American subjects [35]. Effects of such polymorphisms are unlikely in our samples because they were all obtained from Caucasian subjects. Other reasons for SULT2A1 variability in our samples include changes in activity due to sample handling prior to assay or differences in sample location within the small intestine that 

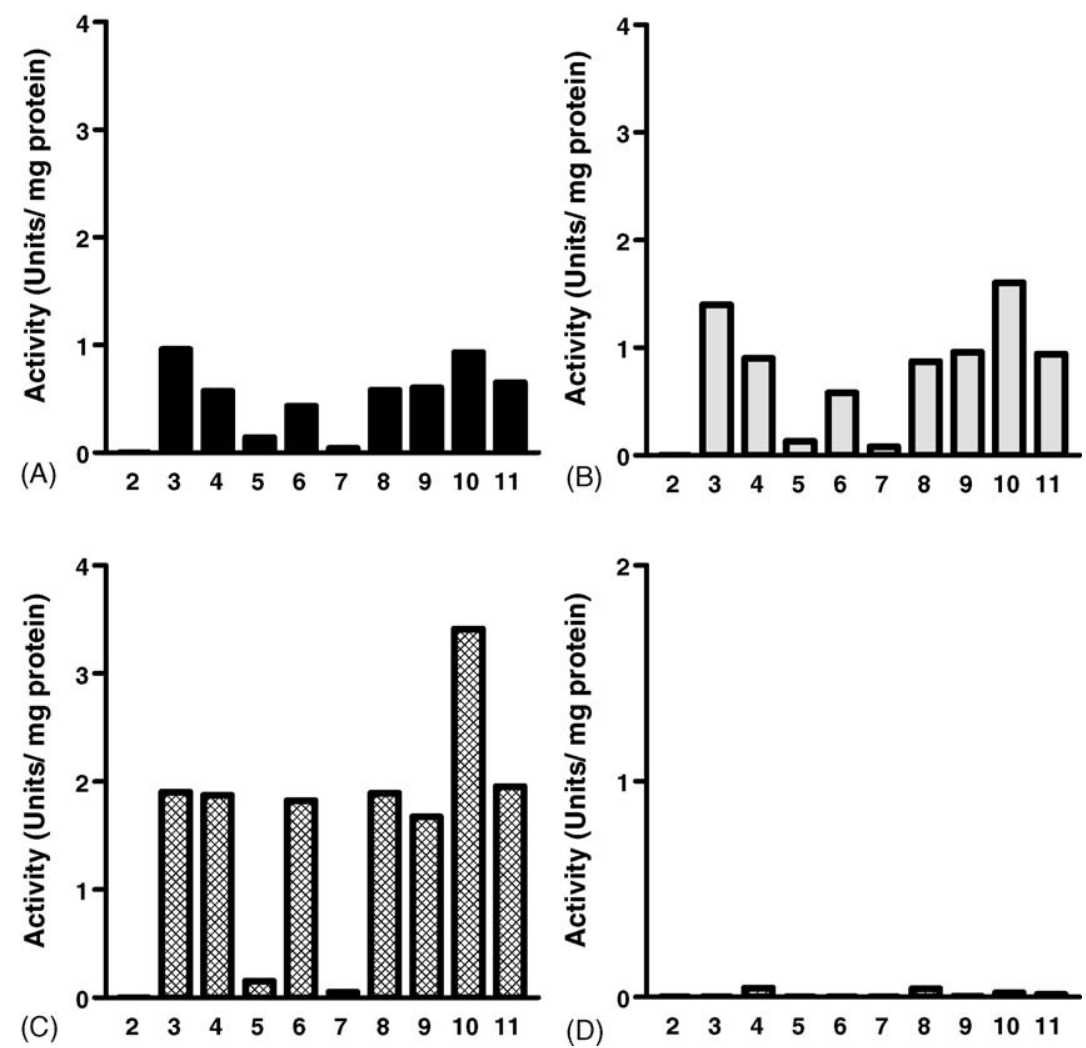

Fig. 5 - Individual postmenopausal liver SULT activities assayed with $1 \mu \mathrm{M} 3 \alpha$-hydroxytibolone (Panel A), $4 \mu \mathrm{M}$ 3 $\beta$-hydroxytibolone (Panel B), $5 \mu \mathrm{M}$ dehydroepiandrosterone (DHEA) (Panel C) and $25 \mathrm{nM}$ estrone (E1) (Panel D with lower activity scale). Activities with hydroxytibolone substrates represent a composite of liver SULT activities (Panels A and B). Results with substrates estrone and DHEA indicate SULT1E1 and SULT2A1 activities, respectively. Each bar represents the mean of three determinations.

would reflect the variable distribution of SULT activities within the gastrointestinal tract [33]. There were no trends to support an association of SULT2A1 activities with the length of time from death to autopsy in our limited number of liver and small intestinal samples. However, the ability to accurately designate the location of the small intestinal sample acquisition supported the use of surgical tissue in future studies. The potential effects, if any, of SULT2A1 activity variations upon intra-hepatic or small intestinal regulation of responses to hydroxytibolone metabolites are not known.

Individual liver SULT1E1 activities were low in both premenopausal and postmenopausal samples. Two of the five premenopausal samples contained substantial SULT1E1 activity and four of the 10 postmenopausal samples contained SULT1E1 activity that was just above the limit of detection for the assay (Figs. 4 and 5). SULT1E1 activity was undetectable in the remaining samples. Reasons other than sample handling for the variations include SULT1E1 genetic polymorphisms that lead to decreased enzyme activity and immunoreactive protein [36] or alterations in the tissue hormonal environment [37]. Our samples were not genotyped for the SULT1E1 allozymes, but this approach in a larger sample of postmenopausal tissues might assist in explaining variations. Changes in SULT1E1 levels have been documented in endometrial tissue as a result of cycling progesterone in premenopausal women and also in women on oral contraceptives that contain progestational agents $[37,38]$. To address the possibility that the SULT1E1 activities in liver and small intestine might change with the variations in the local hormonal milieu, future studies of these tissues from women will require detailed information about their hormonal status.

This report has established the radiochemical enzymatic assay for human postmenopausal liver SULT activities with hydroxytibolone substrates, characterized the SULT biochemical properties with these substrates and identified SULT2A1 as the major contributor to sulfation of these metabolites in postmenopausal tissue. Our documentation of the tissue SULT activities and the resulting sulfated hydroxytibolone metabolites supports the occurrence of pre-receptor enzymatic regulation of estrogen compounds. The results provide a basis for further investigation of the tissue-selective regulation of tibolone effects and emphasize the complexity of steroid hormone sulfation.

\section{Acknowledgments}

We thank Dr. Helenius Kloosterboer, N.V. Organon, Oss, The Netherlands, for the tibolone metabolites and sulfated metabolites for HPLC standards, Dr. Richard M. Weinshilboum, Mayo Foundation, Mayo Clinic, Rochester, MN, for the listed SULT cDNAs, and Cindy Pietsch, VA Medical Cen- 
ter, Omaha, NE, for her assistance in the preparation of this manuscript.

\section{REFERENCES}

[1] Bjarnason NH, Bjarnanson $\mathrm{K}$, Haarbo J, Rosenquist C, Christiansen C. Tibolone: prevention of bone loss in late postmenopausal women. J Clin Endocrinol Metab 1996;81:2419-22.

[2] Lippuner K, Haenggi W, Birkhaeuser MH, Casez J, Jaeger P. Prevention of postmenopausal bone loss using tibolone or conventional peroral or transdermal hormone replacement therapy with 17-estradiol and dydrogesterone. J Bone Miner Res 1997;12:806-12.

[3] Moore R. Livial: a review of clinical studies. Br J Obstet Gynaecol 1999;106(Suppl. 19):1-21.

[4] Kloosterboer HJ, Ederveen A. Pros and cons of existing treatment modalities in osteoporosis: a comparison between tibolone, SERMs and estrogen (+/-progestogen) treatments. J Steroid Biochem Mol Biol 2003;83:157-65.

[5] Kloosterboer HJ. Tibolone: a steroid with a tissue-specific mode of action. J Steroid Biochem Mol Biol 2001;76:231-8.

[6] Genazzani AR, Benedek-Jaszmann L, Hart D, Andolsek L, Kicovic P, Tax L. Org OD 14 and the endometrium. Maturitas 1991;13:243-51.

[7] Egarter C, Huber JC, Leikermoser R, Haidbauer R, Pusch H, Fischl F, et al. Tibolone versus conjugated estrogens and sequential progestogen in the treatment of climacteric complaints. Maturitas 1996;23:55-62.

[8] Erel C, Elter K, Akman C, Ersavasti G, Altug A, Seyisoglu H, et al. Mammographic changes in women receiving tibolone therapy. Fertil Steril 1998;69:870-5.

[9] Ginsburg J, Prelevic G, Butler D, Okolo S. Clinical experience with tibolone (Livial) over 8 years. Maturitas 1995;21:71-6.

[10] Hammar M, Christau S, Nathorst-Boos J, Rud T, Garre K. A double-blind, randomised trial comparing the effects of tibolone and continuous combined hormone replacement therapy in postmenopausal women with menopausal symptoms. Br J Obstet Gynaecol 1998;105:904-11.

[11] de Gooyer ME, Kleyn G, Smits KC, Ederveen AG, Verheul HAM, Kloosterboer HJ. Tibolone: a compound with tissue specific inhibitory effects on sulfatase. Mol Cell Endocrinol 2001;183:55-62.

[12] Blanchard R, Freimuth RR, Buck J, Weinshilboum RM, Coughtrie MW. A proposed nomenclature system for the cytosolic sulfotransferase (SULT) superfamily. Pharmacogenetics 2004;14:199-211.

[13] Falany JL, Macrina N, Falany CN. Sulfation of tibolone and tibolone metabolites by expressed human cytosolic sulfotransferases. J Steroid Biochem Mol Biol 2004;88:383-91.

[14] Otterness DM, Weiben E, Wood T, Watson R, Madden B, McCormick D, et al. Human liver dehydroepiandrosterone sulfotransferase: molecular cloning and expression of cDNA. Mol Pharmacol 1992;41:865-72.

[15] Aksoy IA, Wood TC, Weinshilboum RM. Human liver estrogen sulfotransferase: identification by cDNA cloning and expression. Biochem Biophys Res Commun 1994;200:1621-9.

[16] Her C, Kaur PG, Athwal RS, Weinshilboum RM. Human sulfotransferase SULT1C1: cDNA cloning, tissue-specific expression, and chromosomal localization. Genomics 1997;41:467-70.

[17] Raftogianis RB, Wood TC, Weinshilboum RM. Human phenol sulfotransferases SULT1A2 and SULT1A1: genetic polymorphisms, allozyme properties, and human liver genotype-phenotype correlations. Biochem Pharmacol 1999;58:605-16.

[18] Her C, Wood T, Eichler E, Mohrenweiser H, Ramagli L, Siciliano M, et al. Human hydroxysteroid sulfotransferase SULT2B1: two enzymes encoded by a single chromosome 19 gene. Genomics 1998;53:284-95.

[19] Li X, Anderson RJ. Sulfation of iodothyronines by recombinant human liver steroid sulfotransferases. Biochem Biophys Res Commun 1999;263:632-9.

[20] Kudlacek PE, Anderson RJ, Liebentritt DK, Johnson GA, Huerter CJ. Human skin and platelet minoxidil sulfotransferase activities: biochemical properties, correlations and contribution of thermolabile phenol sulfotransferase. J Pharmacol Exp Ther 1995;273:582-90.

[21] Dubin RL, Hall CM, Pileri CL, Kudlacek PE, Li XY, Yee JA, et al. Thermostable (SULT1A1) and thermolabile (SULT1A3) phenol sulfotransferases in human osteosarcoma and osteoblast cells. Bone 2001;28:617-24.

[22] Li XY, Clemens DL, Cole JR, Anderson RJ. Characterization of human liver thermostable phenol sulfotransferase (SULT1A1) allozymes with 3,3',5-triiodothyronine as the substrate. J Endocrinol 2001;171:525-32.

[23] Anderson RJ, Ebmeier CC. Human anterior pituitary phenol sulfotransferase SULT1A1 and SULT1A3 activities, 12th International Congress of Endocrinology. Medimond 2004:1197-201.

[24] Dooley T, Haldeman-Cahill R, Joiner J, Wilborn T. Expression profiling of human sulfotransferase and sulfatase gene superfamilies in epithelial tissues and cultured cells. Biochem Biophys Res Commun 2000;277:236-45.

[25] Foldes A, Meek JL. Rat brain phenolsulfotransferase-partial purification and some properties. Biochim Biophys Acta 1973;327:365-74.

[26] Anderson RJ, Liebentritt D. Human platelet thermostable phenol sulfotransferase: assay of frozen samples and correlation between frozen and fresh activities. Clin Chim Acta 1990;189:221-30.

[27] Ebmeier CC, Anderson RJ. Human thyroid phenol sulfotransferase enzymes 1A1 and 1A3: activities in normal and diseased thyroid glands, and inhibition by thyroid hormones and phytoestrogens. J Clin Endocrinol Metab 2004;89:5597-605.

[28] Bradford MM. A Rapid and sensitive method for quantitation of microgram quantities of protein utilizing the principle of protein-dye binding. Anal Biochem 1976;72:248-54.

[29] Reiter C, Mwaluko G, Dunnette J, Loon JV, Weinshilboum RM. Thermolabile and thermostable human platelet phenol sulfotransferase. Naunyn Schmiedebergs Arch Pharmacol 1983;324:140-7.

[30] Anderson RJ, Jackson BL, Liebentritt D. Human platelet thermostable phenol sulfotransferase from blacks and whites: biochemical properties and variations in thermal stability. J Lab Clin Med 1988;112:773-83.

[31] Eisenthal R, Cornish-Bowden A. The direct linear plot. A new graphical procedure for estimating enzyme kinetic parameters. Biochem J 1974;139:715-20.

[32] Her C, Szumlanski CL, Aksoy IA, Weinshilboum RM. Human jejunal estrogen sulfotransferase and dehydroepiandrosterone sulfotransferase. Drug Metab Dispos 1996;24:1328-35.

[33] Chen G, Zhang D, Jing N, Falany CN, Radominska-Pandya A. Human gastrointestinal sulfotransferases: identification and distribution. Toxicol Appl Pharmacol 2003;187:18697.

[34] Aksoy IA, Sochorova V, Weinshilboum RM. Human liver dehydroepiandrosterone sulfotransferase: nature and 
extent of individual variation. Clin Pharmacol Ther 1993;54:498-506.

[35] Thomae BA, Eckloff BW, Freimuth RR, Wieben ED, Weinshilboum RM. Human sulfotransferase SULT2A1 pharmacogenetics: genotype-to-phenotype studies. Pharmacogenomics J 2002;2:48-56.

[36] Adjei AA, Thomae BA, Prondzinski JL, Eckloff BW, Wieben ED, Weinshilboum RM. Human estrogen sulfotransferase (SULT1E1) pharmacogenomics: gene resequencing and functional genomics. Br J Pharmacol 2003;139:1373-82.
[37] Rubin GL, Harrold AJ, Mills JA, Falany CN, Coughtrie MW Regulation of sulphotransferase expression in the endometrium during the menstrual cycle, by oral contraceptives and during early pregnancy. Mol Hum Reprod 1999;5:995-1002.

[38] Falany JL, Falany CN. Regulation of estrogen sulfotransferase in human endometrial adenocarcinoma cells by progesterone. Endocrinology 1996;137:1395401. 